\title{
Tafsir-Tafsir Modern dan Kontemporer Abad Ke-19-21 M
}

\author{
Dinni Nazhifah \\ UIN Sunan Gunung Djati Bandung \\ dinni.zhifah.@gontor.ac.id
}

\section{Suggested Citation:}

Nazhifah, Dinni. (2021). Tafsir-Tafsir Modern dan Kontemporer Abad Ke-19-21 M. Jurnal Iman dan Spiritualitas, Volume 1, Nomor 2: pp 211-218. http://dx.doi.org/10.15575/jis.v1i2.12302

\section{Article's History:}

Received 2021-04-13; Revised 2021-05-04; Accepted 2021-05-04.

2021. journal.uinsgd.ac.id @. All rights reserved.

\begin{abstract}
Abstrak:
Al-Qur'an selalu mengemukakan pendapat atau motto "shalih fii kulli zaman wa makan", dalam artian tidak adil menerima begitu saja apa yang diungkapkan secara harfiah, tetapi mencoba untuk melihat konteks dan makna dibalik ayat-ayat AlQur'an. Dengan kata lain yang ingin dicari adalah "spirit" atau moral pesan dari Al-Qur'an itu sendiri. Interpretasi modern dan kontemporer yang selalu di dorong untuk menyesuaikan dengan kemajuan yang mungkin menjadi factor utama dalam melahirkan dan meningkatkan tanggapan penerjemah mufassir. Artikel ini mencoba menggambarkan keadaan beberapa karya tafsir moder dan kontemporer yang berkembang pada abad ke 29-21 M. Diakhir pembahasan tersebut penulis menyimpulkan bahwa moder dan kontemporer di dominasi oleh Pendidikan berbasis filsafat Al-Qur'an, Al-Qur'an dan sejarah alam, surat kabar dan actual muslim dailu. Disini penulis juga menyimpulkan bahwa interpretasi modern dan kontemporer Ketika mengandung makna yang kuat bagi ummat islam baik masalah sehari-hari, serta dukungan kongkret obyektif untuk perkembangan pengetahuan manusia.
\end{abstract}

\section{Kata Kunci: tahlili, ijmali, tafsir kontemporer}

\section{Abstract:}

Al-Qur'an always puts forward the opinion or motto "shalih fii kulli zaman wa makan". It is not fair to accept what is expressed literally but tries to see the context and meaning behind the verses of the Al-Qur'an. In other words, what you want to look for is the "spirit" or moral message of the Qur'an itself. Modern and contemporary interpretations are always encouraged to adapt to the progress that may be the main factor in giving birth and increasing the response of interpreter translators. This article tries to describe some of the modern and contemporary exegetical works that developed in the 19-21 century AD. At the end of the discussion, the writer concludes that the modern and modern are dominated by education based on the philosophy of the Qur'an, the Qur'an and natural history, newspapers, and the actual Muslim dailu. Here the author also concludes that modern and contemporary interpretations contain strong meanings for the Islamic ummah, daily problems, and objective, concrete support for the development of human knowledge.

\section{Keywords: tahlili, ijmali, contemporary interpretation}

\section{PENDAHULUAN}

Al-Qur'an adalah kitab suci yang di dalamnya memuat hidayah (petunjuk) dan ajaran moral universal bagi semua umat manusia sepanjang zaman (Taufiq \& Suryana, 2020). Pada hakikat ini al-Qur'an dipercaya dan diyakini tidak akan lapuk dan habis dikekang zaman. Akan tetapi pada kenyataanya, banyak dari teks al-Qur'an yang difahami secara parsial dan ideologis yang berdampak kurang baik terhadap tafsir, yang menyebabkan seolah kajian tafsir Al-Qur'an menjadi teks yang mati dan tak lagi relevan dengan perkembangan zaman. Banyak presepsi para pembaharu memandang bahwa pemahaman Al-Quran jalan ditempat, mereka memandang bahwa metodologi klasik telah menghilangkan ciri khas Al-Quran sebagai kitab suci yang sempurna yang sesuai dengan zaman (Zulaiha \& Dikron, 2020).

Secara sekilas tafsir kontemporer tidak berbeda juah dengan tafsir klasik, keduanya memang difokuskan untuk menyelaraskan pesan Al-Qur'an sesuai dengan zamanya (Zulaiha, 2017). Namun di masa modern dampak kemajuan teknologi dan ilmu pengetahuan menjadi factor utama yang mengarah pada tuntutan baru. Menurut para mufassir modern kontemporer, yang dibutuhkan pada masa ini adalah model dan metodologi dalam penafsiran dan pehaman Al-Quran, agar kitab suci ini tetap menjadi kitab suci yang sempurna dan selalu relevan dengan setiap zaman. Dan mampu menjawab semua masalah social kegamaan yang dihadapi oleh umat islam pada masa ini (Riyani \& Huriani, 2017). 
Kemajuan teknologi dan ilmu pengetahuan merupakan suatu dorongan besar yang mengharuskan penafsiran Al-Quran sesuai dengan zaman, dan ini merupakan factor terbesar yang menjadikan para ulama melahirkan karya karya baru. Mereka meyakini bahwa banyak dari umat islam belum memahami secara dalam tentang apa yang disampaikan Al-Quran (Rahman, 2010).

Sebagaimana kalangan fuqaha, kaum modernis juga menafsirkan dan memahami Al-Quran sesuai dengan pemikiran mereka. Mereka meyakini bahwa penafsiran AI-Quran tidak hanya dikhususkan untuk ulama terdahulu, akan tetapi terbuka untuk setiap muslim. Dalam pandangan pembaharu ini, muffasir klasik selalu menyesuaikan karya mereka dengan zamannya. Maka penafsiran periode sekarang harus diorientasikan ke masa kini.

Artikel ini secara khusus akan menjelaskan macam-maacam tafsir yang muncul pada abad ke 19-21 M, terkait dengan identitas penulis kitabnya, bagaimana metode penafsirannya dan karakteristik yang membedakan dengan karya tafsir yang lainnya.

\section{HASIL DAN PEMBAHASAN \\ Al-Tafsīr Al-Bayāni Li Al-Qur’ān Al-Karīm Karya 'Āisyah ‘Abdurrahmān Bintu Syāt \{l\{' Tafsir Linguistik Biografi}

Nama lengkap beliau adalah Aisyah Abdurrahman Almukaanat Bintu Syati', beliau adalah seorang aktivis perempuan, seorang penulis yang aktif di mesir, seorang pembaharu dan seorang dosen di universitas Kairo Fakultas Adab Jurusan Sastra Arab. Nama Bint asy Syathi' merupakan nama yang dipakai saat ia menulis karena dibesarkan dan dilahirkan di tepian sungai Nil.. Bint asy Syathi' mempunyai arti anak perempuan pinggiran (sungai). Beliau lahir di Dumyat tanggal 6 dzuhijjah 1331 hijriah yang bertepatan dengan tanggal 6 november 1931 masehi (Al-A'lamiyah, 1999). Beliau dibesarkan dikalangan keluarga yang kental dengan keilmuan, shaleh, dan taat, Ayahnya adalah salah satu Syaih di salah satu sekolah keagamaan di dimyat. Syekh Ali Abdurrahman sang ayah sangat menginginkan memiliki seorang putra, jadi ketika memiliki putri kedua dia bersumpah akan memberikan pendidkan agama yang kuat dan akan dibesarkan dengan pendidikan islam yang benar (Al-Nadwi, 1963).

Dengan semangat belajar yang tinggi, pada tahun 1939 ia telah mendapat gelar sarjana Sastra Arab, Fakultas Adab Universitas Kairo, dan juga berhasil menyandang gelar Magister di tahun 1941 dengan predicate Summa Cumlaude (AlA'lamiyah, 1999). Bintu Syati' dipinang oleh, DR. Amin Khulli, beliau adalah salah satu dosen Bintu Syati', beliau dikenal sebagai sarjana Islam yang berdedikasi tinggi dan ia juga salah satu dari kaum intelektual yang sering berkecimpung dalam problematika pendidikan.

\section{Karakteristik Tafsir dan Metode penafiranya}

Aisyah Bint Syati menjadi guru besar di fakultas adab di universitas Al-azhar Kairo Mesir, dan juga di sekolah tinggi khusus wanita, dan selama perjalananya menutut ilmunya bintu syati menulis beberapa tafsir dari beberapa surat pendek didalam alquran. Maka terbitlah buku tafsir bintu syati yang berjudul "Al-Tafsīr Al-Bayāni Li Al-Qur'ān Al-Karīm". Buku tafsir tersebut dicetak menjadi dua bagian, Bintu Syati mempersembahkan karyanya tersebut untuk guru dan suaminya.

Bintun syati' sengaja memilih 14 surat pendek sebagai lahan garapan penafsiranya. Jilid pertama terdiri dari 7 surat, yaitu: 1 . al-Duhā, 2. al-Insyirah, 3. al-Zalzalah, 4. al-Nāzi'āt, 5. al-Ādiyat,6. al-Balad, dan 7. al-Takaslur. cetakan edisi pertama yang dipublikasikan pertamakali pada tahun 1962 masehi dikeluarkan oleh percetakan Daarull Ma'arif. Dan cetakan selanjutnya di cetak pada tahun 1966 dan 1968 (Thahari, 2009). Jilid yang kedua terbit pada tahun 1969 dan jilid kedua ini mendapat sambutan yang luar biasa dari para public. Edisi ke dua ini berisikan 7 surat: 1. al-Alaq, 2. al-Qalam, 3. al-Asr, 4. al-Lail, 5. alFajr,6. al-Humazah, dan 7. al-Mā'ūn.

Edisi pertama tafsir Bintu Syati' ini memuat tujuh surat makkiyyah yang secara umum kita ketahui bahwa surat makiyyah adalah surat yang di turunkan di Mekkah, sebelum nabi Muhammad Hijrah Madinah pada tahun 622 M (Al-Qathân, 1997). Tujuh surat pendek diatas mencangkup didalamnya kajian teologis (akidah) dan ajaran moral. Dan tema tentang hukum islam tidak ditemukan kecuali hanya menyinggung sedikit. Tapi dari siniditemukan satu kesatuan tema yaitu tentang nilai keberagamaan yang bermuara pada empat poin: 1. Ilustrasi huru hara kiama, 2. Nuansa hari akhir, 3. Moralitas dan kepedulian kepada sesame, 4. Deskripsi tentang misi sebagai rasul.

Motivasi Bintu Syati membuat tafsir ini tertusli didalam kata pengantar tafsirnya, ia meyatakan bahwasanya ia hanya berusaha menafsirekan surat surat pendek secara bayāni dan mukjizatnya yang kekal. la berusaha semaksimal mungkin memurnikan pemahaman nas qur'ani dengan menampakkan ruh bahasa Arab berikut temperamennya, mengenali setiap lafalnya, serta setiap gerakan dan aksennya dalam uslub Al-Qur'an (Thahari, 2009). Alasan Bintu Syati memilih tentang gaya bahasa al-Qur'an dan surat surat pendek karena surat memiliki ciri khas mempunyai ayat yang pendek. Secara retoris, lependekanya menunjukan kekuatan, ketegasan, tidak bertele tele dan membangkitkan keseriusan bagai siapa saja yang mendengarkanya.

Prinsip prinsip metode yang di kemukakan Amīn al-Khūli menurut Bintu Syati merujuk kepada empat hal: Pertama, metode penafsiranya berbasis tafshir Maudhu'l atau tafsir Tematik yaitu dengan cara mengumpulkan semua surat dan ayat yang ada didalam al-Qur'an kedalam tema yang dikaji. Kedua, untuk bisa memahami nash menurut konteksnya, maka ayat ayat yang di susun harus sesuai dengan kronologi pewahyuanya untuk mengetahui situasi, tempat, pelaku dsb. Ketiga, untuk memahami petunjuk kata (dilālah al-lafz\} i) yang termuat didalam al-quran harus dikupas secara dalam arti lingustik aslinya dalam berbagai penggunaan, baik yang bersifat haqiqi atau yang bersifat majazi. Dengan demikian makna al-quran di telusuri 
dengan cara mengumpulkan seluruh bangunan bentuk kata tersebut didalam al-quran, sehingga diketahui makna umum dan khusus dari kata tersebut. Contoh: ketika Bintu Syati menafsirkan kata نشط dalam ayat gالنشاطة, beliau terlebih dahulu mengurai arti dari bangunan kata tersebut, kata tersebut terdiri dari huruf: nūn, syīn, dan t\}ā'. Setelah diketahui artinya maka dibandingkan dengan pendapat mufassir yang lainya terutama mufassir klasik, beliau sering merujuk al-Ragīb al-lsfahāny. Barulah beliau memutuskan bahwa arti kata tersebut adalah lepas dengan mudah (Thahari, 2009). Keempat, dalam memahami rahasia ungkapan Bintu Syati' mengikuti konteks nash yaitu berpagang kepada makna atau semangatnya. Kemudian makna tersebut dibandingkan untuk direkonstruksi, dan disesuaikan dengan konteks ayat.

Dari sini dapat disimpulkan bahwa buku tafsir milik Bintu Syati': metode penafsiran berdasarkan mashdar, termasuk tafsir muqqoarin karena dalam menafsirkan tafsirnya Bintu Syati mengumpulkan juga aspek sufistik aspek ra'yi. Lalu dari segi tartibu ayat tafsir ini adalah tafsir Mauduh'i karena mengumpulkan lafadz-lafadz yang serupa lalu menjelaskanya menurut maudhu' dan pemakaianya. Dan corak tafsirnya adalah corak tafsir bayaani atau linguistik (Asubhaanii, 2001).

Para mufassir terdahulu yang sering dijadikan rujukan antara lain: 1. al-Tabari, 2. al-Zamakhsyari, 3. Fakhruddīn al-Rāzi, 4. al-Ragīb al-Isfahāni, 5. Ibn Qayim al-Jauziyah, 6. al-Suyūt\}i, dan 7. Muhammad Abduh.

\section{Tafsiir Al-Ayat Al-Kauniyyah Fii Al-Quran Al-Kariim Karya Zaghloul El-Naggar \\ Biografi}

Nama lengkap beliah adalah Doktor Zaghloul Ragheb Muhammad el-Naggar, dilahirkan pada tanggal 17 November tahunn 1933 di salah satu kota kecil di Mesir yang berlokasi di Provinsi Algharbia (Khir, 2000). Beliau adalah seorang yang cerdas dalam bidang Geologi, sarjana Muslim, dan penulis Muslim. la memiliki banyak buku yang bertema kitab-kitab elNaggar adalah ilmu pengetahuan dalam Al-Qur'an, ia mengintegrasikan antara filsafat, ilmu dan ilmu dengan agama.

Dia adalah seorang kepala organisasi al-l'jaz al-'Ilmi Li Qur'an wa as-Sunnah di Advanced Organization of Islamic Majorors, Mesir Dia adalah master geologi di beberapa universitas terkenal di negara-negara Arab dan Barat, la juga seorang anggota terhormat Institut Sains Islam (Al-Najjar, 2007).

la menempuh pendidikan di Universitas Kairo sehingga bergabung dengan fakultas sains dilanjutkan dengan studi geologi yang merupakan bidang baru baginya, dan mendapatkan gelar Ph. D. pada tahun 1963 dari University of Wales, Inggris tahun 1963, karena kecemerlangannya dalam sains dan ilmu keislaman yang membuatnya memenuhi syarat untuk mendapatkan banyak penghargaan, di waktu yang sama dan universitas yang sama, ia dianugerahi Robertson-Post Doctoral Research, Arab Petroleum Congress Best Paper Award tahun 1970, sehingga ia dianugerahi juga sebagai Baraka Geology. Hadiah dari universitas pertamanya (El-Naggar, 1991).

\section{Karya-Karya Zaghlul Raghib Muhammad Annajar}

Zaghloul el-Naggar dimahkotai dengan kapasitas tinggi untuk mengumpulkan kekayaan besar. la memiliki kemampuan yang luar biasa dalam banyak aspek kehidupan, bahkan dalam bisnis, keuangan, real estate, sains, penerbitan dan lain-lain, hal ini menjadikan tema dominan dari buku-buku, ceramah, dan artikel Zaghloul el-Naggar telah diimpor secara ilmiah dari Alquran. Beliau telah banyak menulis buku-buku yang berisi tentang ilmu pengetahuan dan al-Qur'an, beberapa diantaranya adalah:

1) The Geological Concept of Mountains in the Quran, buku ini adalah referensi yang bagus untuk mengetahui gunung dalam Alquran, seperti kata-katanya di dalamnya "Kata gunung dalam bentuk tunggal dan jamak disebutkan secara eksplisit dalam Alquran. 39 kali ( 6 dalam bentuk tunggal dan 33 dalam bentuk jamak), dan secara jelas diimplikasikan sebagai stabilisator untuk kerak bumi dalam 10 ayat lainnya (El-Naggar, 1991).

2) Tafsir Aayat Al-Kauniyyah Fii Al-Quran Al-Kariim. Buku ini berisikan sekitar 4 jilid, masing-masing kitab menjelaskan tentang ayat-ayat kosmos yang terdapat dalam Alquran di setiap Surah, untuk jilid pertama, mulai dari al-Baqarah hingga al-Isra ', jilid kedua mulai dari al-Kahf sampai Luqman, jilid ketiga as- Sajdah sampai al-Qomar, dan untuk jilid keempat terakhir dimulai dari ar-Rahman sampai al-Qori'ah (Annajar, 2008).

3) Wonderful Scientific Signs in the Qur'aan, buku ini berisi tentang wawancara antara Zaghloul el-Naggar dan Ahmad Faraaj tentang masalah keilmuan al-Qur'an yang indah, pidato pada bab pertama tentang hikmah di balik keliling. dari Ka'bah, gelap dan terang, laut dan sungai serta air tawar dan air asin, bab kedua mencakup tentang penciptaan laut, bola langit, langit dan bumi, air dan bumi, air adalah asal kehidupan di alam semesta manapun dan Tuhan menurunkan air murni dari langit, bab ketiga adalah membelah bulan.

Sebenarnya ia memiliki lebih banyak masterpiece dari yang disebutkan di atas, karena keterbatasan peneliti, ia hanya dapat menyebutkan sebagian kecil dari karya besarnya sebagai buku.

\section{Karakteritik Tafsir dan Metode Penafsiranya}

Kitab-kitab tafsir ang diperkenalkan oleh Zaghloul el-Naggar memfokuskan kepada ayat-ayat kauniyyah yang terdapat dalam al-Qur'an al-Karim. Tidak heran bahwasanya beliau hanya membahas ayat-ayat yang berorientasikan kauniyyah yang hanya terdapat 66 surat dalam al-Qur'an.

Melalu telaah penulis, tafsir ini pada asasnya merupakan kajian beliau yang bersifat maudhu'i, yaitu beliau menafsirkan ayat-ayat tertentu berdasarkan topikal. Keunikan tafsir ini yakni keseluruhan ayat yang dibahas bukan saja diolah melalui analisis metodologi klasik, tapi juga memuat bukti saintifik untuk membuktikan keunggulan dan keontentikan al-Qur'an dalam 
multi dimensi. Kehebatan beliau dalam menggabungkan ilmu syar'iyyah dan ghayr syar'iyyah, atau menurut Ibn al-Qayyim ilmu naqliyyah dan ilmu 'aqliyyah, dalam tafsir ini menjadikan beliau sebagai pelopor dalam menerapkan data-data saintifik dalam penafsiran al-Qur'an (Annajar, 2001).

Jika diamati, Zaghloul el-Naggar menyusun karyanya berdasarkan metode penulisan klasik dan modern. Manhaj dari segi penyusunan klasik yang paling dikekalkan oleh beliau ialah penyusunan ayat pembahasan atau surat mengikuti susunan seperti yang terdapat di dalam al-Qur'an. Dimulai dengan surat al-Baqarah hingga surat an-Nas. Namun perlu diketahui bahwa pemilihan ayat yang dituju dalam tafsir ini menjurus kepada ayat-ayat al-Qur'an yang berkaitan sengan sains natural. Hal ini berdasarkan bidang keeahlian utama beliau yang meliputi penemuan saintifik melalui dimensi alam semesta, penciptaan makhluk dan kedokteran. Dan yang menarik dari tafsir beliau yakni, beliau ahanya membahas atau menafsirkan ayat-ayat tertentu saja, tidak membahas topik yang tidak berkaitan sama sekali sengan sains natural. Maka tidak heran jika tafsir 'ilmi beliau disebut sebagai ensiklopedia tafsir penemuan saintifik al-Qur'an yang modern. Beberapa metode tafsir 'ilmi Zaghloul elNaggar adalah sebagai berikut:

1) Analisis topik

2) Integrasi antara ilmu pengetahuan umum dan modern dengan ilmu agama.

3) Unsur-unsur keimanan akan Sang Pencipta

4) Verify penafsirannya dengan Sunnatullah atau Hadith.

5) Mengkombinasikan penafsirannya dengan ulama lain

6) Mengkombinasikan antara ilmu syar'iyyah dan ilmu ghayr syar'iyyah.

Bagaimanapun, dia secara keseluruhan telah menafsirkan ayat-ayat Alquran secara tematik, karena dia menafsirkan halhal utama dan menjelaskan secara totalitas bukan di setiap kata ayat. Dan masyarakat hanya diperbolehkan untuk membuktikan keajaiban ilmiah al-Qur'an, dengan memanfaatkan fakta absolut dan hukum ilmiah. Dan ketentuan ini umumnya berlaku untuk semua ayat kosmologis dalam al-Qur'an, kecuali ayat penciptaan, bahkan tentang makhluk hidup alam semesta dan manusia.

\section{Tafsîr Fî Zilâl al-Qur'ân Karya Sayyid Qutub Biografi}

Sayyid Quthb ialah seorang ahlitafsir, ilmuan, dan juga sastrawan, tidak hanya itu beliau juga adalahsalah satu pemikir dari Mesir. la banyak menulis dalam berbagai bidang. la mempunyai nama lengkap Nama Sayyid Quttub bin Ibrahim bin Husain Asyaadzilii, beliau lahir di daerah Asyut tahun $1326 \mathrm{H}$. Beliau hidup atau tumbuh dikalangan keluarga yang memiliki tradisi keagamaan yang kental (Ali lyyazi, 1993).

Pada tahun $1918 \mathrm{M}$, dia berhasil menamatkan pendidikan dasarnya. Lalu ia melanjutkan pendidikannya di Madrasah Tsanawiyah Pada tahun 1921. Pada masa mudanya, sayyid qhutub pindah ke Helwan dan tinggal dengan pamannya, Ahmad Husain Ustman ia merupakan seorang jurnalis. Pada tahun $1925 \mathrm{M}$, ia masuk ke institusi diklat keguruan, dan lulus tiga tahun kemudian. Lalu ia melanjutkan jenjang perguruannya di Universitas Dâr al-Ulûm hingga memporelah gelar sarjana (Lc) dalam bidang sastra sekaligus diploma pendidikan (Ali lyyazi, 1993). Adapun beberapa karya Sayyid Qutub dari Kutubu Al-Islamiyyah antara lain:

1) Tafsîr Fî Zilâl al-Qur'ân

2) Ma'aliimu Thariq

3) Khasaaishu Al-Islamii

\section{Metode penafsiran}

Nama lengkap buku tafsir beliau adalah Tafsîr Fî Zilâl al-Qur'ân, awal nya ini adalah judul rubik yang dikelola oleh Sayyid Qutub atas permintaan Sa'id Ramadhan dalam majalah bulanan yang Al-Musliimun, sebuah jurnal yang diterbitkan pertma kali pada bulan Desember 1951. Tulisan pertamanya, tafsir al-Fâtihah muncul dalam al-Muslimûn edisi ketiga, Februari 1952, kemudian disusul tafsir surat al-Baqarah. Sayyid Qutb lahir pada bulan September 1906 di Koha, wilayah Ashyut\}, Mesir (AlUsmawî, 2001).

Enam belas volume pertama Fî Zilâl al-Qur'ân diterbitkan pada periode antara Oktober 1952 hingga Januari 1954. Sedangkan sisanya di selesaikan ketika Sayyid dalam penjara Rezim Gamal Abdl Nasr Dalam menafsirkan ayat al-quran Sayyid Quthub mengggunakan metode penafsiran tematik, yaitu: beliau terlebih dahulu memberikan gambaran tema-tema yang ada didalam surat tersebut, setelah itu beliau melakukan pengelompokan ayat untuk ditafsirkan (Ali lyyazi, 1993).

Jika ada ayat ayat yang tidak memerlukan takwil maka beliau tidak akan ditakwilkan lebih jauh karena, beliau lebih condong dalam penolakan takwil. Penolakan itu hanya berlaku pada ayat-ayat tertentu. Dengan demekian, dalam penafsiran Sayyid Qutb beliau membatasi rung lingkup paranan akal.

\section{Tafsîr al-Marâghî Karya Ahmad Mustafâ bin. Muhammad bin Abd al-Mun'îm al-Marâghî Biografi}

Beliau memiliki nama lengkap Ahmad Musthafa bin Muhammad bin Abdul Mun'im al-Maraghi. Terkadang nama tersebut dilengkapi dengan memakai kata Beik, sehingga menjadi Ahmad Musthafa al-Maraghi Beik. Al-Maraghi beliau lahir dikota Maraghhah, yaitu sebuah kota atau kabupaten di tepi barat sungai Nil (Ali lyyazi, 1993). Beliau memiliki lingkungan keluarga 
yang sangat tekun dalam menyelami ilmu pengetahuan dan peradilan, sampai keluarga mereka dikenal sebagai keluarga hakim.

Masa kanak-kanaknya dilalui dalam lingkungan keluarga yang religius. la menempuh pendidikah dasarnya disebuah Madrasah di desanya, tempat ia belajar Alquran, memperbaiki bacaan al-Qur'an, dan menghafal ayat-ayatnya, hingga sebelum menginjak usia 13 tahun ala-maraghi sudah hafal seluruh ayat Alquran. Tidak hanya itu, ia juga mempelajari ilmu tajwid dan jugsadasa-dasar ilmu agama yang lainya. Pada tahun 1314 H./1897 M al-maraghi menyelesaikan pendidikan dasarnya, dan dengan didukung kedua orangtuanya ia meneruskan pendidikanya ke Universitas al-Azhar Kairo. Dia juga mengambi kuliah di Universitas Darul 'Ulum Kairo (Mahmud, 2006). Meski sangat sibuk di dua perguruan tinggi ini, al-Maraghi layak disebut sebagai orang yang rajindan tekun, sebab keduanya berhasil diselesaikan pada saat yang bersamaan, yaitu ditahun 1909 M.

\section{Karya-Karya Al-Maraghi dan Motivasi menulis Tafsir}

Ulama kontemporer terbaik yang dimiliki oleh Islam salah satunya adalah Al-Maraghi. Dari kecil ia sudah mengabdikan dirinya pada ilmu pengetahuan dan agama. Selain menjadi guru besar di beberapa lembaga pendidikan dan sekolah tinggi, ia juga mewariskan beberapa karnya. Salah satu di antaranya karyanya adalah Tafsi-r al-Maraghi, yaitu kitab tafsir yang muncul pada abad ke 14 (Shiddieqy \& Hasby, 2003). dan tersebar juga dikenal di seluruh dunia Islam sampai sekarang. Karyakaryanya yang lainnya diantaranya:

1) Al-Hisbat fi al-Islâm

2) Al-Hisbat fi al-Islâm

3) 'Ulûm al-Balâghah

4) Muqaddimat at-Tafsîr

5) Buhûts wa A-râ' fi Funûn al-Balâghah; dan

6) Ad-Diyânat wa al-Akhlâq

Latar belakang beliau menulis tafsir adalah, kenyataan yang sempat disaksikan, bahwa kebanyakan orang enggan membaca kitab-kitab tafsir yang ada ditangan sendiri. Dengan alasan kitab-kitab tafsir yang telah ada sangat sukar dipahami, bahkan diwarnai dengan berbagai macam istilah yang hanya bisa dimengerti oleh orang-orang yang ahli di bidang ilmu tersebut. Karenanya dengan ini, maka dirinya termotivasi untuk menulis tafsir dengan sengaja mengubah gaya tatanan bahasa dan menyuguhkanya dalam bentuk yang sederhana dan mudah dipahami (Al-Maraghi, n.d.).

\section{Metode penafsiran Al-Maraghi}

Tidak dipungkiri bahwa penyusan tafsir Al-Maraghi tidak terlepas dari unsur-unsur tafsir sebelumnya., terutama tafsir AlManar milik Muhammad Abduh dan Rasyid Ridha, karena beliau berdua adalah guru dari Al-Maraghi yang tak hentinya memberikan bimbingan kepada beliau. Hal ini terlihat dari corak penafsiran beliau yang modern. yaitu Tafsir lughawi (adabi). Bahkan banyak orang yang memandang bahwa Tafsîr al- Marâghî adalah penyempurnaan terhadap Tafsîr al-Manâr. Metode yang dipakai juga dipandang sebagai pengembangan dari metode yang di terapkan dan dipapaki pada tafsir Al-Manar (AlMaraghi, n.d.).

Dalam menafsirkan Al-Maraghi mengembangkan metodologi baru, ia memisahkan antara uraian rinci dan global sehingga penjelasan ayat-ayat di dalamnya dibagi menjadi dua kategori, yaitu ma'na ijma-li dan ma'na tahlili. Kemudian, dilihat dari sumber yang dipakai selain memakai ayat dan atsar, ia juga memakai ra'yi (nalar) sebagai sumber dalam penafsiran ayatnya. Namun perlu ditekankan kembali, penafsiran beliau yang bersumber dari riwayat (relatif) terjaga dari riwayat yang lemah (dha'if) dan sulit diterima akal atau tidak didukung oleh bukti-bukti secara ilmiah.

Langkah-langkah dan sistematika penulisan yang dipakai dalam Tafsir al-Maraghi diantaranya adalah (Ali lyyazi, 1993):

1) Menjelaskan satu, dua, atau beberapa ayat yang akan ditafsirkan. ini dilakukan agar bisa melihat kesatuan inti atau pokok bahasan. Ayat-ayat ini diurutkan sesuai tertib ayat di dalam mushaf mulai dari surah al-Fatihah hingga surah anNas (Metode tafsir tahlili).

2) Penjelasan kosa kata (syarh al-mufradat). Yaitu dengan memaparkan beberapa kosa kata yang sulit menurut ukurannya. Dengan begitu, tidak semua kosa kata dalam sebuah ayat dijelaskan akan tetapi dipilih hanya beberapa kata yang bersifat konotatif atau sukar bagi pembaca..

3) Menjelaskan Asbabun nuzul

4) Penjabaran dan penjelasan (al-Idhah).

\section{Tafsîr al-Manâr Karya Muhammad Abduh \\ Biografi}

Nama lengkapnya adalah Muhammad bin Abduh bin Hasan Khairullah, beliau dilahirkan pada tahun $1894 \mathrm{M}$, di desa Mahallat Nashr kota Buhairah (Shihab, 2006). Muhammad Abduh sebelum belajar secara formal, ia belajar baca tulis di rumah orang tuanya, kemudian pindah ke sekolah Hifzil Quran (Mahmud, 2006). Kemudian Muhammad Abduh dikirim oleh ayahnya ke Mesjid al-Ahmadi Thantha (sekitar 80 km dari Kairo) untuk mempelajari tajwid al-Quran. Namun, sistem pengajaran di sana dirasakan sangat menjengkelkannya sehingga setelah dua tahun (tahun 1864) di Thantha, Muhammad Abduh memutuskan untuk kembali ke desanya dan bertani seperti saudara-saudara serta kerabatnya. 
Pada tahun 1882 M Pasca-Revolusi Urbani berakhir dengan kegalalan, pemerintah Mesir mengira bahwa Muhammad Abduh ikut serta terjadinya kegagalan tersebut. Sehingga pemerintah Mesir mengasingkan Abduh ke Suriah selama tiga tahun. Abduh hanya selama setahun di Suriah, ia berhijrah ke Paris, Perancis menyusul al-Afghani, yang sebelumnya juga diusir oleh Pemerintah Mesir. Mereka menerbitkan surat kabar al-Urwah al-Wusqa dengan tujuan untuk menentang penjajahan Barat, khususnya Inggris.

\section{Karya- Karya Muhammad Abduh dan Metode penafsiranya}

Sebagaimana sebelumnya sudah disinggung sedikit terkait karya Muhammad Abduh terkait tafsir yaitu Tafsir al-Qur'an al-Hakim yang lebih popular dikenal denganTafsir al-Manar.Tafsirini pada mulanya merupakan diktat perkuliahan Abduh tentang tafsir Al-Qur'an di Universitas Al-Azhar.Sepeninggalan Abduh tafsir tersebut disusun kembali oleh Muhammad Rasyid Ridha yang merupakan murid dari Abduh. Tafsir al-Manar diterbitkan setelah dilakukan pengolahan dan pengeditan seperlunya.

Di dalam metode penafsiranya Muhammad Abduh tidak ingin ada keterkaitanya dengan mufassir terdahulu, tetapi ia lebih banyak mengombinasikan antara riwayah shahih dan juga nalar akal rasional yang diharapkan bias menjelaskan hikmah syariat serta eksistiensi al-quran sebagai kitab hidayah bagi manusia (Ridha, 2007). Salah satu kitab tafsir yang menjadi rujukanya adalah Tafsîr Jalâlayn (Al-Dzahabi, 2012). Disini terdapat adanya perbedaan antara murid dan gurunya yaitu antara Rida dan Muhammad Abduh jika Abduh tidak banyak menukil pendapat mufassir terdahlu, maka Rida banyak menukil pendapat para ulama terdahulu atau klasik (Ali lyyazi, 1993).

Al-Dzahabi menyebut bahwa model penafsiran Muhammad Abduh adalah pembaharuan (tajdid), dorongan untuk terbebas dari taqlid (mengikuti dogma tertentu secara buta), memberikan ruang pikiran untuk bebas berfikir, dan menjauhi kejumudan dari pendapat-pendapat ulama terdahulu (Al-Dzahabi, 2012). Muhammad Abduh mengatakan di Muqaddimah Tafsir Al-manar: "Aku tidak membaca (kitab-kitab tafsir) ketika aku membacakan Alquran, namun ketika aku menemukan halhal asing dalam i'rab aku membuka kitab tafsir para ulama" (Al-Dzahabi, 2012).

Secara umum sebenarnya metode yang dipakai dalam tafsir Al-Manār tidak jauh berbeda dengan kitab-kitab tafsir yang lain yang menggunakanmetode Tahlili dengan menerapkan sistematika tertib Mushafi.

\section{Tafsir Al-Misbāhn Karya Quraish Shihab \\ Biografi}

Muhammad Quraish Shihab lahir pada 16 Februari 1944 M di kota Rappang, provinsi Sulawesi Selatan. Ayah Quraish Shihab adalah Abdurrahman Shihab (Ghafur, 2008), yaitu guru besar dalam bidang tafsir pernah menjadi rector IAIN. Pada tahun 1958 M, Quraish berangkat ke Kairo dengan bantuan dari beasiswa Pemerintahan Sulawesi Selatan. Quraish mengenyam pendidik di Mesir dari kelas II Tsanawiyah hingga meraih gelar MA pada tahun 1967 M. Quraish sempat pulang ke Indonesia pada tahun $1980 \mathrm{M}$ walaupun tidak lama dikarenakan ia melanjutkan program doktoral di Universitas Al-Azhar dan mengharuskan ia untuk kembali lagi ke Kairo. Quraish menyelesaikan program doktoral selama dua tahun dengan yudisium yang sangat bagus yaitu summa cum laude dengan penghargaan tingkat I dan tercatat sebagai orang pertama di Asia Tenggara yang meraih gelar doctor dalam bidang ilmu-ilmu Al-Qur'an di Universitas Al-Azhar (Shihab, 2001).

Setelah kembali ke Indonesia, pada tahun 1984, Pada tahun 1995, Quraish Shihab ditugaskan di fakultas Ushuluddin dan Program Pascasarjana IAIN Syarif Hidayatullah Jakarta dan beliau dipercaya menjadi Rektor IAIN Syarif Hidayatullah Jakarta. Dan itu memberikan kesempatan untuk merealisasikan gagasan-gagasanya, salah satu diantaranya melakukan penafsiran dengan menggunakan pendekatan multidisipliner, yaitu pendekatanyang melibatkan sejumlah ilmuwan dari berbagi bidang spesialisasi. Menurutnya, hal ini akan lebih berhasil untuk mengungkap petunjuk dari al-Qur'an secara maksimal (Kasmantoni, 2019).

\section{Karya-Karya Quraish Shihab}

Sebagai penulis yang produktof dan juga mufassir kontemporer. Banyak dari tulisan dan karya beliau yang telah diterbitkan. Diantara karyanya ada beberapa yang khusus berkaitan dengan studi al-Qur'an diantaranya: Tafsir Al-Manar: Keistimewan dan Kelemahannya (1984), Filsafat Hukum Islam (1987), Mahkota Tuntunan Illahi: Tafsir Surat Al- Fatihah (1988), Membumikan Alquran: Fungsi dan Peranan Wahyu dalam Kehidupan Maysarakat (1994), Studi Kritik Tafsir al-Manar (1994), Lentera Hati: Kisah dan Hikmah Kehidupan (1994), Wawasan Alquran: Tafsir Maudhu'i atas Berbagai Persoalan Umat (1996), dan lain sebagainya.

Beberapa karya Quraish Shihab diatas menandakan bahwa ia memiliki peranan dalam perkembangan keilmuan di Indonesia khususnya yang berkaitan dengan al-Qur'an. Dari sekian banyak karyanya, Tafsir Al-Misbah, merupakan mahakarya beliau yang sangat besar. Dari buku tafsir inilah nama beliau mulai dikenal sebagai salah satu mufasiir Indonesia yan mampu menafsirkan 30 juz dari volume 1 sampai 15.

\section{Corak Tafsir Al-Misbah dan Metode}

Yang melatarbelakangi quraish shihab dalam menulis tasr al-misbah adalah: karena kesemangatan beliau untuk bisa memunculkan karya tafsir Alquran kepada masyarakat secara normatif dikobarkan oleh apa yang dianggapnya sebagai suatu fenomena melemahnya kajian dan khazanah keilmuan Alquran sehingga Alquran tidak dijadikan untuk pedoman hidup dan 
sumber rujukan dalam mengambil suatu keputusan. Menurut Quraish dewasa ini masyarakat Islam lebih terpesona pada lantunan bacaan Alquran, seakan-akan kitab suci Alquran hanya diturunkan untuk dibaca.

Didalam menafsirkan ayat quraish shihab tidak langsung menafsirkan ayat tersebut, akan tetapi terlebih dahulu ia memberikan pengantar berupa: nama surah dan nama lain surah tersebut, jumlah ayat (terkadang ada penjelasan tentang perbedaan penghitungan), tempat turun surah (makiyyah dan madaniyyah), keterkaitan (munasabah) antara surah sebelum dan sesudahnya, dan sebab turun ayat (asbabun nuzul), nomor surat berdasarkan urutan mushaf dan urutan turunnya kadang disertai nama-nama surat yang turun sebelum maupun sesudahnya, dan yang terakhir memberikan kesimpulan yang global disetiap alhir penafsiran (Shihab, 2002).

Dilihat dari sistematika penulisan, tafsir Al-Misbah termasuk kedalam tafsir dengan tartib mushafi, yaitu penafsiran yang menggunakan perurutan ayatnya sesuai dengan mushaf al-Qur'an, yaitu surat yang pertama kali di tafsirkan adalah al-fatihah dan yang terakhir adalah surat annaas.

Metode yang digunakan oleh quraish shihab juga cenderung memakai metode tahlili, sebagaimana pada umumnya tafsir yang menggunakan tartib mushafi. la menafsirkan dengan menganalisa terlebih dahulu secara kronologis dan menjelaskan beberapa aspek yang terkandung dalam ayat tersebut sesuai dengan urutan dan bacaan mushah. Hal ini diunakan guna membuktikan bahwa surah-surah serta ayat-ayat dalam Al-Qur'an mempunyai keserasian yang sempurna dan merupakan satu kesatuan yang tak dapat dipisah-pisahkan (Mahmud, 2006).

Dari sisi kebahasaan Quraish Shihab memperhatikan dengan sangat teliti kaidah bahasa arab. Yang dimana bahasa arab adalah pegangan dengan bertumpu pada ilmu gramatika bahasa arab (Nahwu) dalam menjelaskan makna kosa kata. Perhatian yang besar quraish shihab dalam aspek kosa kata bisa dilihat ada disetiap ayat yang ditafsirkanya. Selain itu ia mencoba mencari argumen atau dasar filosofis kenapa satu kata di dahulukan dari kata yang lain, tetapi pada ayat yang lain diakhirkan. Corak tafsir Al-Misbah juga bisa dikatakan corak ijtima'l atau kemasyarkatan, sebab uraiannya mengarah kepada masalah yang berlaku di masyarakat

Corak (laun) Tafsir ini sangat jelas menggunakan model al- tafsir bi al ma`tsur atau al-tafsir bi al-riwayah atau al-tafsir bi al-manqul. Ciri tafsir timur tengah sangat kentara dalam tafsir al- Mishbah ini.Quraish dalam penafsirannya banyak mengambil riwayat- riwayat sebagai sumber penafsiran, yang disandarkan pada ayat-ayat al-qur'an, hadis-hadis nabi yang diriwayatkan oleh para sahabat, tabi'in dan tabi' al-tabi' in (kutub al-sittah) (Shihab, 2002). Walaupun mengambil bentuk tafsir ma'tsur, Quraish Shihab memberikan ruang untuk pemikiranya sendiri sehingga tafsir ini juga bisa dianggap tafsir bi al-ra`y.

\section{KESIMPULAN}

Perkembangan tafsir antara masa banyak memiliki keterkaitan yang kuat. Hal ini karna adanya perangkat yang disepakati dalam menafsirkan Al-Qur'an, hingga tidak mudah untuk membedakan karya tafsir masa klasik dengan pariode sesudahnya. Sejauh penelusuran terhadap tafsir abad modern saat ini, dapat dijelaskan bahwa tafsir modern dan kontemporer di dominasi oleh kajian-kajian filosofi Al-Qur'an, tentang Al-Qur'an dan sejarah alam, serta Al-Qur'an adalah pegangan dan masalah actual dalam kegiatan sehari-hari bagi ummat islam yang ada di seluruh dunia. Kecenderungan ini tidak saja menjadi tuntutan modernitas dalam berbagai bidang termasuk tafsir, namun juga semakin derasnya perkembangan ilmu pengetahuan pada abad-abad millennium ke dua. Sudah bisa dipastikan bahwa sebuah tafsir dapat eksis dan berkembang pada masa modern sekarang ini, bila mengandung signifikasi yang kuat dengan masalah keseharian ummat islam, sekaligus memberikan dukungan yang kongkrit dan obyektif terhadap perkembangan pengetahuan manusia saat ini.

\section{DAFTAR PUSTAKA}

Al-A'lamiyah, A. A.-A. (1999). Muassasah A'mal Al-Mausu'ah Lil Nasrh wa At-Tauzi'. Al-Mamlakah Al-Arabiyyah AsSu'udiyyah.

Al-Dzahabi, M. H. (2012). Al-Tafsir Wa Al-Mufassirun. Dar al-Hadith.

Al-Maraghi, A. M. (n.d.). Muqaddimah Tafsir Al-Maraghi. Al-Mamlakah Al-Arabiyyah As-Su'udiyyah.

Al-Nadwi, A. B. (1963). Bayna al-Tasawuf wa al-Hayat. Damaskus: Dar Al-Fath.

Al-Najjar, Z. R. (2007). Buku pintar sains dalam hadis: mengerti mukjizat ilmiah sabda Rasulullah saw. Zaman.

Al-Qathân, M. (1997). Mabâhits fî 'Ulûm al-Qur'ân. Kairo: Maktabah Wahbah.

Al-Usmawî, A. S. (2001). al-Shâhid Sayyid Qutb. Dâr al-Da,awât.

Ali lyyazi, M. (1993). Al-Mufassiruun Hayaatuhum Wa Manhajihi. Muassasah Atiba'ah wa Anshr Wazirah Astsaqofah wa AlIrsyad Al-Islamii.

Annajar, Z. R. M. (2001). Qodliyyat al-l'jaz al-'Ilmiy li al-Qur'an al-Karim wa Dlawabith al-Ta'amul Ma'aha. Maktabah al-Syururq al-Daulah.

Annajar, Z. R. M. (2008). Tafsir Aayatu Al-Kauniyyah i Fii Al-Qur'an Al-Kariim. Maktabah Asyruq Addauliyyah.

Asubhaanii, J. (2001). Al-manahij At-Tafsiir Fii Uluumul Qur'an. Al-Mausu'ah Imam As-Shadiq A'laihi Wasslam.

El-Naggar, Z. (1991). The Geological Concept of Mountains in the Quran. ScribeDigital. com.

Ghafur, S. A. (2008). Profil Para Mufassir Al-Qur'an. Yogyakarta: Pustaka Insan Madani, 197.

Kasmantoni, K. (2019). تطوبر المقرر ودواد تعليم الصرف التطبيفى في ضوء المدخل الوظبفي: بالتطبيق على طلبة قسما Universitas Islam Negeri Maulana Malik Ibrahim.

Khir, B. M. (2000). The Qur'an and Science: The Debate on the Validity of Scientific Interpretations. Journal of Qur'anic Studies, 
2(2), 19-35.

Mahmud, M. H. (2006). Metodologi Tafsir: Kajian Komprehensif Metode Para Ahli Tafsir. Jakarta: RajaGrafindo Persada.

Rahman, M. T. (2010). Pluralisme Politik. WAWASAN: Jurnal IImiah Agama Dan Sosial Budaya, 34(1), 1-13.

Ridha, M. R. (2007). Tafsîr al-Qur'ân al-Hakîm al-Syahîr bi Tafsîr al-Manâr. Beirut: Dar Al-Fikr, t. Th.

Riyani, I., \& Huriani, Y. (2017). Reinterpretasi Asbāb Al-Nuzūl bagi Penafsiran Alquran. Wawasan: Jurnal IImiah Agama Dan Sosial Budaya, 2(1), 113-130.

Shiddieqy, T. M. H. A., \& Hasby, M. (2003). Sejarah dan Pengantar Ilmu al-Qur'an dan Tafsir (Semarang: PT. Pustaka Rizki Putra.

Shihab, M. Q. (2001). Mu'jizat al-Qur'an Ditinjau dari Aspek Kebahasaan. Isyarat IImiah Dan Pemberitaan Gaib (Bandung: Mizan.

Shihab, M. Q. (2002). Tafsir al-misbah. Jakarta: Lentera Hati, 2.

Shihab, M. Q. (2006). Rasionalitas Al-Qur'an: Studi Kritis atas Tafsir Al-Manar. Lentera Hati.

Taufiq, W., \& Suryana, A. (2020). Penafsiran Ayat-Ayat Israiliyyat dalam Al-Qur'an dan Tafsirnya (E. Zulaiha \& M. T. Rahman (eds.)). Prodi S2 Studi Agama-Agama UIN Sunan Gunung Djati Bandung.

Thahari, F. (2009). Tafsir Berbasis Linguistik: al-Tafsīr al-Bayāni li al-Qur'ān al-Karīm Karya Aisyah Abdurrahman binti Shați'. Jurnal Adabiyyat, 8(2), 66.

Zulaiha, E. (2017). Tafsir Kontemporer: Metodologi, Paradigma dan Standar Validitasnya. Wawasan: Jurnal IImiah Agama Dan Sosial Budaya, 2(1), 81-94.

Zulaiha, E., \& Dikron, M. (2020). Qira'at Abu 'Amr dan Validitasnya. Prodi S2 Studi Agama-Agama UIN Sunan Gunung Djati Bandung. conditions of the Creative Commons Attribution (CC BY SA) license (http://creativecommons.org/licenses/by-sa/4.0/). 